\title{
RADICAL TPACHER
}

A SOCIALIST, FEMINIST, AND ANTI-RACIST JOURNAL ON THE THEORY AND PRACTICE OF TEACHING

\section{Professional Decline and Resistance: The Case of Library and Archives Canada}

\author{
By Tami Oliphant and Michael B. McNally
}

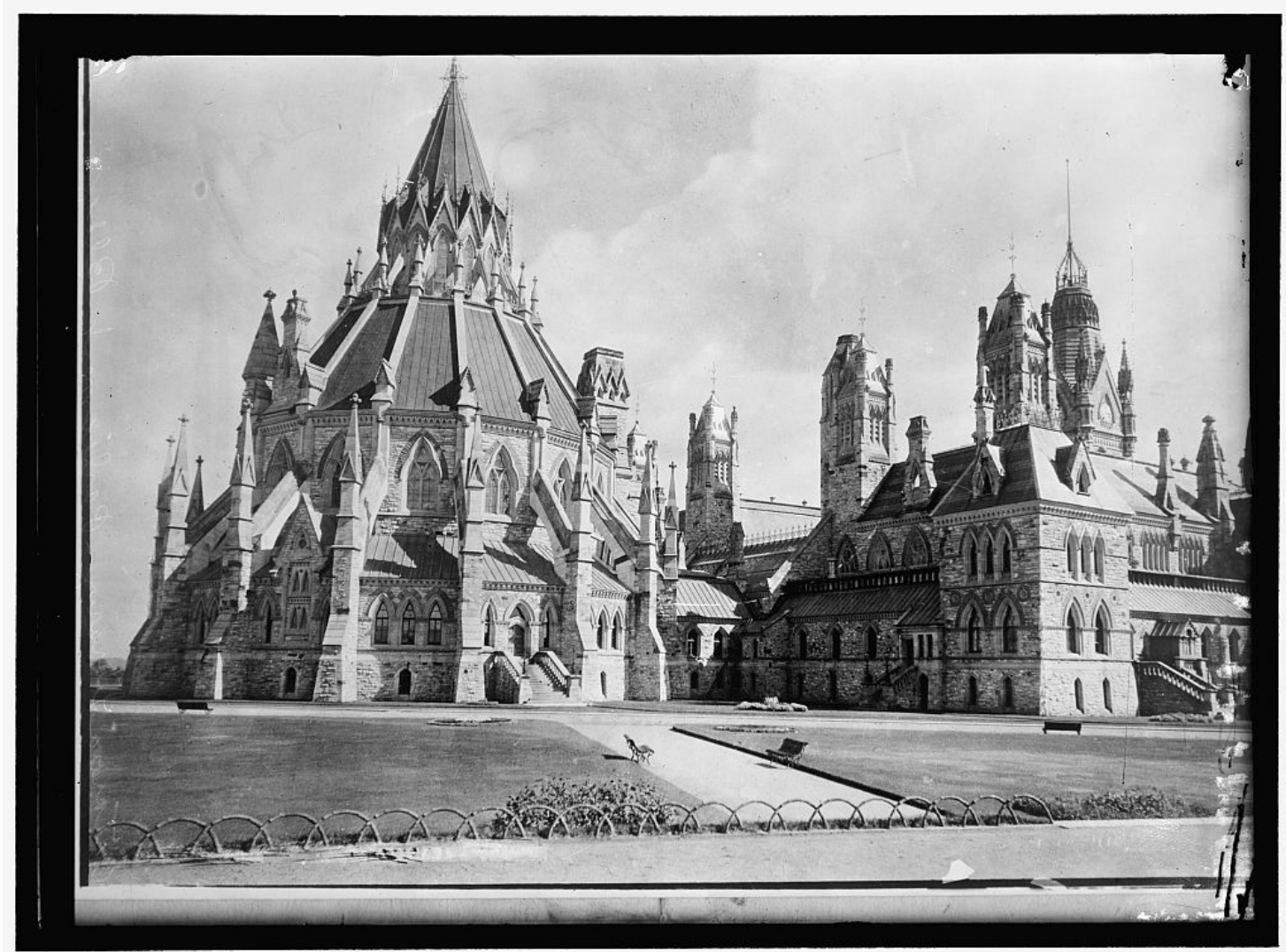

OTTOWA LIBRARY. COURTESY LIBRARY OF CONGRESS 
I n 2004, Canada was the first country in the world to amalgamate its two main documentary heritage institutions, the National Archives of Canada (established in 1872) and the National Library of Canada (established in 1953) into one institution: Library and Archives Canada (LAC). Later that year, LAC released a discussion paper, Creating a New Kind of Knowledge Institution, which outlined its new controversial "modernization" policy: the LAC would be transformed from an institution focused on acquisitions and preservation to one focused on digital access and preservation. This shift in policy was justified by the assumption that new technology would make LAC more cost-efficient while rendering many core services obsolete.

However, "modernization" has brought drastic reductions in number and quality of services, collections, and collaboration. Furthermore, staff has been subject to continual budget cuts, uninspired and controversial leadership, and a draconian employee Code of Conduct (LAC, 2010). Ten years after the implementation of the modernization policy, LAC has been unable to fulfill its mandate to "preserve and make accessible Canada's documentary heritage as well as serve as the continuing memory of the Government of Canada and its institutions." Recent events at LAC demonstrate how market logic and rationalization can systemically weaken public institutions by reducing and commercializing services while deprofessionalizing and casualizing the work of professionals.

The ongoing crisis at Library and Archives Canada is part of the governing Conservative Party's attempt to deprofessionalize all federal employees, including scientists, and fulfill an ideological mandate to create the smallest government in Canada in 50 years. Resistance has come from many stakeholders across Canada: historians, researchers, and organizations such as the Association of Canadian Archivists and the Bibliographic Society of Canada. Responses by the Canadian Association of University Teachers (CAUT) and the Canadian Library Association (CLA) are particularly salient. Both are national organizations concerned with access to information and Canada's documentary heritage. In addition, many members of CAUT and CLA themselves work in postsecondary education, libraries, archives, and other institutions where deprofessionalization is an everyday reality. CAUT and CLA responded differently to the crisis at the LAC because they framed the issues in distinct ways.

"modernization" has brought
drastic reductions in number and
quality of services, collections, and
collaboration. Furthermore, staff
has been subject to continual
budget cuts, uninspired and
controversial leadership, and a
draconian employee Code of
Conduct

The case of LAC is illustrative in two regards. It demonstrates the ongoing precarity of federal employees even in the face of resistance from professional organizations. More importantly, it demonstrates how a neoliberal remaking of one prominent, national institution can weaken entire professions. This article examines that process in detail, and considers two strategies of resistance to the attack on archivists and librarians in Canada.

\section{Trouble at Library and Archives Canada}

In the scope of its activities and responsibilities, the former National Archives of Canada was comparable to the United States' National Archives and Records Administration. In the United States, the Library of Congress supports Congressional decision making and serves as a national library for bibliographic materials. In Canada these functions are split, with the Library of Parliament supporting legislative research and decision making, and the National Library of Canada serving as a depository. With the creation of LAC, "Canada is to be served by an institution that is a source of enduring knowledge accessible to all, contributing to the cultural, social and economic advancement of Canada as a free and democratic society," according to the enabling act (Canada, 2012).

In 2009, the conservative government appointed Daniel Caron to head LAC. His appointment and tenure have been controversial. Though he had a master's degree in economics, a doctoral degree in applied human sciences, and extensive experience in the federal government, he lacked any background in either library and information science or archival studies (Library and Archives Canada, 2009).

\section{The ongoing crisis at Library and Archives Canada is part of the governing Conservative Party's attempt to deprofessionalize all federal employees, including scientists, and fulfill an ideological mandate to create the smallest government in Canada in $\mathbf{5 0}$ years.}

In a 2010 speech Caron suggested that the biggest potential problem facing librarians and archivists was irrelevance, and that technological change threatened the practices and theoretical underpinnings of librarianship and archival science (Caron, 2010). Fears of obsolescence are not new, for these (or other) professions, but Caron's proposed solution was alarming. He suggested that archivists and librarians should converge, thus sharply altering their professional identities. "Information professionals must remake themselves, not simply through peripheral adjustments, but through a complete reinvention" (Caron, 2010). While outsiders' predictions of professional demise often result from a misunderstanding, having the National Librarian and Archivist suggest that librarians and archivists reinvent themselves and merge devalues professional knowledge and builds anxiety about 
job security. Caron clearly viewed his role in LAC as one of radical restructuring, based on his view that professional expertise can be superseded by technology.

Furthermore, during testimony before a parliamentary committee, Caron suggested that the manual cataloguing of new materials by LAC was outdated, and that the institution could simply rely on information provided by publishers as a justification for drastic cuts in digitization and circulation staff: "Much of this type of work [cataloguing/description] is becoming increasingly unnecessary. That includes the description of archival materials," (Caron, 2012). While publishers provide some description, the quality and consistency of their work is not comparable to that of trained librarians and archivists. Caron's comments demonstrate his lack of familiarity with the core work of both professions, and-given that he speaks as National Librarian and Archivist-threatens their standing.

In early 2013 the controversies focused on a new employee Code of Conduct. The 23-page Code, which includes a loyalty policy and extensive guidelines on personal activities, became public in March 2013. Officially, the Code stems from a management review audit by the Treasury Board Secretariat of Canada (roughly the Canadian equivalent of the Office of Management and Budget in the United States). The audit concluded that LAC should do more to prove its employees were acting in accordance with federal values and ethics statements (LAC, n.d.). However, the Code's reach goes far beyond the Treasury Board's own guidelines for federal public employees (Treasury Board Secretariat, 2011).

The Code outlines a duty of loyalty (to the government not the public); conflicts of interest; personal activities (e.g., teaching and speaking at conferences, personal engagements, and political activities); and makes the conflict of interest provisions binding for a full year after an employee leaves LAC (LAC, 2013b). The Code identifies teaching or speaking engagements in classrooms and conferences as "high risk," and states that those who lobby, supply, collaborate, or advocate with or for LAC should not engage in those activities. LAC's legal mandate is "to facilitate cooperation among communities involved in the acquisition, preservation, and diffusion of knowledge," but the Code severs a basic connection between LAC's librarians and archivists and their professional communities across Canada.

Of special concern is the deep conflict between the Code and the professional ethics of LAC employees. Archivists and librarians are governed by well-established professional codes of ethics and principles developed by the American Library Association and the Canadian Library Association over a century of public service. One core principle of librarianship is upholding intellectual freedom, of which the CLA states:

It is the responsibility of libraries to guarantee and facilitate access to all expressions of knowledge and intellectual activity, including those which some elements of society may consider to be unconventional, unpopular or unacceptable (1985).

This is difficult to reconcile with the LAC Code. Librarianship places great value on unfettered access to information, but the Code suggests that staff refrain from commenting at all on the actions of the government or LAC in classrooms, conferences, or any social media or other public forum. Critics suggest that the "Code is a means for the LAC to undermine professional ethics and identities as a part of a broader attempt by the LAC to deprofessionalize and de-skill its workforce" (Martinello, 2013). Staff are caught in a double-bind. The Code makes it impossible for them to guarantee and facilitate access to all expressions of knowledge and information (including government information). Furthermore, LAC employees themselves do not enjoy freedom of expression at their workplace due to the provisos outlined in the Code. It deprofessionalizes them in two ways: they are unable to fulfill their obligation to guarantee access to information; and they are unable to express unpopular or unconventional ideas and opinions in their own practice and workplace.

In addition, the Code explicitly states that employees have a duty of loyalty to the Government of Canada and its elected officials (read Conservative Party), which extends so far as to recommend that staff exercise caution in

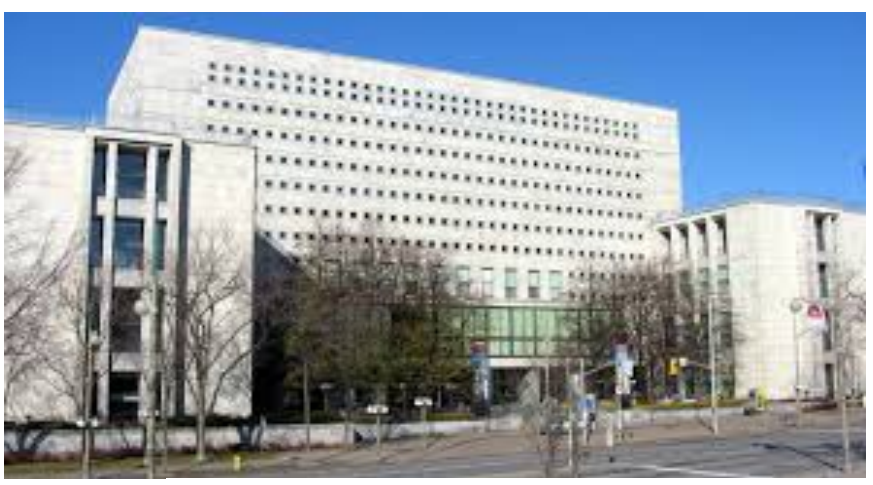

LIBRARY AND ARCHIVES CANADA

expressing personal opinions and making public comments that could damage LAC's reputation (LAC, 2013b). Not only does the Code prevent employees from engaging in scholarly discourse and professional engagement, it permeates employees' personal lives and infringes upon their freedom of expression by advocating self-censorship.

Under Caron's leadership, services have withered. The Canadian Genealogy Centre has seen a $40 \%$ reduction in service hours, reference services have been reduced from 30 hours a week to by-appointment-only; and in 2012, LAC ceased delivering interlibrary loans to other libraries across Canada (LAC, 2013c). Many of these changes are due to significant budget cuts. In its March 2012 Budget, the Canadian federal government cut the operating budget of LAC by $\$ 9.6$ million each year for a three-year period as part of its deficit reduction plan. In response, the LAC sent notices to about $20 \%$ of its employees advising them that their positions could be eliminated and that they could be laid off. Indeed, $20 \%$ of the staff was cut (CAUT, 2012). While funding for the LAC has varied over the past ten 
years, staffing levels were relatively constant until the announced budget cuts for the 2012-2013 financial year.

The reduction of services and hours of operation means that conducting research using LAC materials is much more time-consuming and costly. For example, LAC failed for more than two months in 2013 to make 92-yearold census data accessible to the public. When it finally made good on its obligation, it did so in partnership with Ancestry.ca. LAC conceded, "paid access will only be necessary if someone wants the extra convenience of doing advanced searches from home" (LAC, 2013a). The Ancestry.ca deal reflects the significance of the cuts and the ideology driving these changes in a number of ways. The rhetoric used by the LAC--"extra convenience" and "advanced searches from home"--portrays these services as going far beyond what a user should expect. LAC is diminishing user service expectations. In addition, not only was it unable to fulfill its mandate and make 1911 census data available to the public in 2013, it outsourced the work to a for-profit genealogical company. Outsourcing public services to the private sector weakens the professions by narrowing their jurisdictions and implying that the market is the logical source for "extra" services.

\section{While Canadian academics currently enjoy greater security than academics in the United States, casualization and deprofessionalization of academic work is occurring in Canada as well.}

Taken together, the Code of Conduct, Caron's belief that the library and archival professions should converge, the shedding of core professional work such as cataloguing, all serve to deprofessionalize LAC's staff. Such neoliberal initiatives typify the conservative government's attempts to undermine the federal civil service. More specifically, these actions undermine Canada's library and archival community, the country's primary cultural memory organization.

The numerous shortcomings of LAC have been met with a range of criticisms from historians, researchers, the general public, academics, and professional associations, including a mock funeral in Ottawa to commemorate the death of Canada's heritage, and the Bibliographic Society of Canada's letter-writing campaign to every single member of Parliament. Responses by the Canadian Association of University Teachers and the Canadian Library Association are particularly instructive. They show how two national organizations with vested interests approach the issues of de-skilling, the casualization of labor, and the ideology of market logic. While CAUT strategized a grassroots letter-writing and "Save Library \& Archives Canada" campaign, the CLA opted for an Executive Council, top-down "engagement" strategy with the LAC and Canadian government. These different strategies exemplify different conceptions of the fight against deprofessionalization.

\section{The Canadian Library Association}

Founded in 1946, the Canadian Library Association is considered the national voice for "Canada's library communities." It represents the interests of academic, public, school, and special libraries. Its mission is to champion library values such as intellectual freedom, diversity, and universal access to library service, publicize the importance of libraries, influence public policy, and collaborate to strengthen the library community (Canadian Library Association, 2013a). Missing from this list is any expression of support for, and advocacy on behalf of, library workers (degreed librarians, library technicians, and other library staff) or the broader library and information professions.

While the Canadian government calls CLA a lobby, CLA does not. Its policy documents describe its lobbying efforts as "advocacy," on a model of influence and engagement. It emphasizes building relationships with elected officials and government bureaucrats and using its influence "not for professional gain, but for the public good" (Moore, 2012a). The use of the term "advocacy" rhetorically distances the CLA from political positions on labor. For example, during a strike at the library and archives at the University of Western Ontario, CLA refused to support striking workers, explaining, "As the Canadian Library Association, we count both libraries and all those who work in libraries as members. We cannot and will not indicate support for one side over another in the case of dispute or strike" (Lockhart, 2012). Similarly, the CLA declined to take a position on behalf of professional librarians and archivists in their dealings with the government, throughout the LAC crisis.

\section{The Canadian Association of University Teachers}

By contrast, from its inception in 1951, the Canadian Association of University Teachers has been ". . . the national voice for . . . 68,000 teachers, librarians, researchers, general staff and other academic professionals." CAUT supports collective bargaining and "actively advances" the social and economic interests of its members. Private universities are uncommon in Canada and there is no "accreditation body" that oversees universities. Canadian universities are governed by provincial and territorial legislatures and the majority of funding for postsecondary education comes from provincial and territorial governments. Within this context a strong, national voice such as CAUT is essential.

In addition, while Canadian academics currently enjoy greater security than academics in the United States, casualization and deprofessionalization of academic work is occurring in Canada as well. CAUT has broadly resisted it. Changes at LAC fall under CAUT's mandate to support researchers, advance the development of knowledge, and protect Canada's documentary heritage.

\section{CAUT and CLA's responses to the LAC crisis}

Critiques began in earnest in 2011 in response to LAC service cuts that were launched under the "modernization initiative." In 2011, CAUT published its "Backgrounder" document and launched its "Save Library \& Archives" campaign. It called for LAC to restore public services, 
"including access to archivists and librarians; access to the general reference collection; and re-establishment of specialist archivist positions" (CAUT, 2011c) and included an online toolkit, letter-writing campaign, and blog documenting changes at LAC and CAUT's interactions with the federal government.

In an open letter to Daniel Caron dated June 27, 2011, CAUT identified many problems at LAC, and included a critique of Caron's background: "it is worth noting that all former National Librarians and National Archivists were trained librarians, historians or recognized writers... Your background in human resource management is a marked departure from this tradition. . . "(CAUT, 2011a). The letter reported on shortcomings at LAC in quality and quantity of service and diminished access. It also made several references to the minutes from the LAC's own Stakeholder Forum in 2010, noting that "the number of employees in the library sciences group at LAC has dropped significantly over the past several years" and that "our sources indicate that the numbers of librarians and archivists in senior management positions at LAC have been significantly reduced" (CAUT, 2011a). From its inception, CAUT's campaign focused as much on casualization of labor and deprofessionalization as on access to materials, acquisitions, and commercialization of services.

CLA President
Karen Adams
responded that her
organization shared
some of CAUT's
concerns "particularly
in the areas of

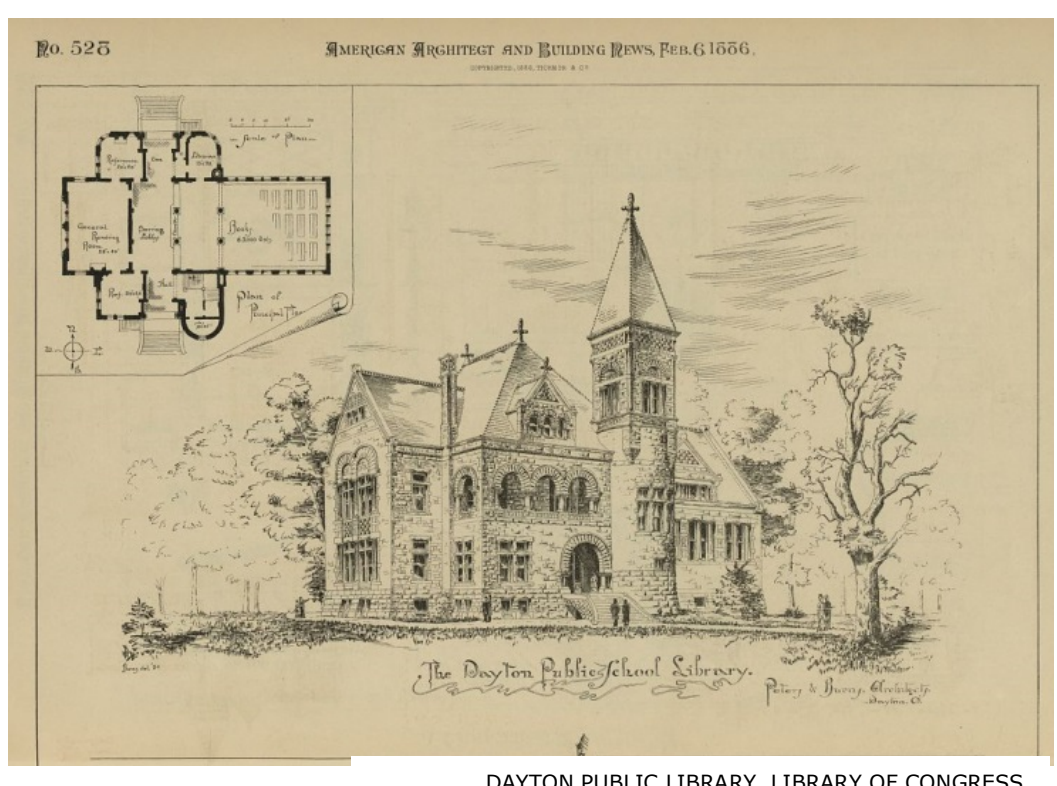

acquisitions and the provision of services by qualified professional staff" but that ultimately the changes at LAC were a reflection of the difficult federal budget situation (Adams, 2011). Despite acknowledging that the changes would affect quality of service and acquisitions and thereby undermine the professional work of librarians and archivists and reduce access to materials by users, CLA reiterated that engaging government officials about these issues was the most pressing concern.

The first official CLA response to the federal budget cuts in 2012 was the most vociferous it would be in its criticism (Adams, 2012b; CLA, 2012b). The letter stated that LAC would be unable to meet the expectations of the library and archival community, noted that the nation's collective memory was at risk, and asked the government to "re-evaluate its spending priorities" (Adams, 2012b). However, merely one month after the letter was sent, the CLA had significantly weakened its criticism. The reasons for its change in tone are not apparent. Its Executive Council now stated that the CLA's strategy would be enhanced engagement, and that it "supports LAC management in making informed choices about the changes they must make in light of their budget restrictions" (CLA, 2012a). CLA had moved from opposing the government's fiscal priorities to accepting the cuts as necessary. In contrast, CAUT's Save LAC campaign renewed criticism of the cuts, especially as they reduced digitization staff.

By late 2012, findings from the CLA's membership survey revealed the internal discord around its "influence" strategy. Anonymized comments from members included statements such as, "It seems that the CLA has not been a strong voice for championing concerns about the new directions of LAC," "I really hope that the CLA will be doing more than just contacting MPs [Members of Parliament]," "I don't feel that CLA has been very vocal about its support of libraries. Too often it seems that the CLA is not willing to take a strong stance," and "My concern is that the CLA is not being assertive enough in regards to LAC, and that the existing efforts have been to try and work with the cuts, rather than to argue against them, or resist them" (CLA, 2012c). Criticism of the influence approach went as far as calling for the resignation of the Executive Council. Karen Adams noted in an editorial that the "perceived failure" of CLA owed to its having chosen "the path of engagement" (Adams, 2012a).

In response to internal criticisms, CLA posted a statement on the controversial Code of Conduct, saying that it "restricts unnecessarily the ability of librarians and information professionals to perform key aspects of their work, namely teaching and speaking at conferences and other public engagements. . . and the categorization of those activities as 'high risk,' effectively eliminate the possibility that librarians may engage in essential elements of their work . .. that benefit ... the greater professional community"... ." (CLA, 2013b). CLA's address to the professional crisis is explicit here. Grassroots efforts of its membership were responsible.

The sudden resignation of Caron in May of 2013, amid allegations of extravagant personal misspending, reinforced the change in CLA's advocacy. It now argued that the incoming LAC head should have either library or archival qualifications (Martinez, 2013). A week later, a "Joint Statement on Qualities of a Successful Librarian and Archivist of Canada," a two-page list of desired qualifications, was sent to the Minister of Canadian Heritage (Joint Statement, 2013). CLA endorsed it, along 
with 18 other cultural memory associations. (CAUT publicized its own list of qualifications.)

The crisis had revealed a crucial problem for CLA's advocacy model: finding the right balance among interests of libraries, the public, and the profession. The influence and engagement approach is appropriate chiefly when librarians are dealing with budget allocations from governments. Furthermore, CLA's professional ethic of upholding intellectual freedom in libraries can be a contentious issue for some stakeholders. But with the exception of its emphasis here on professional credentials, it has continued to support libraries by building relationships with the government and the public. It cannot in this way unequivocally represent professional interests. Some members of CLA clearly want it to take a firmer position on support for libraries and on professional values. Many are frustrated by CLA's refusal to act on behalf of library workers. The crisis at LAC suggests that information professionals in Canada need a national organization focusing on labor.

It is instructive to compare the effectiveness of the resistance strategies of these two organizations. CAUT fulfilled its mandate by strongly advocating for labor, for the profession, and for researchers. The CLA distanced itself from that strategy, and opted for a less confrontational approach. But neither CAUT nor CLA has been able to block the concentrated effort of the federal government to deprofessionalize the federal civil service.

\section{Resisting deprofessionalization}

Since the early 1980 s neoliberal leaders in Canada (as in many other countries) have launched attacks on public workers. Conservative Prime Minister Stephen Harper has weakened the federal bureaucracy more than any of his predecessors. The attack goes far beyond LAC. A 2013 report by the Professional Institute of the Public Service of Canada, a union representing 60,000 federal employees, notes that of the 4,069 scientists surveyed, $90 \%$ feel they cannot speak freely to the media, and $86 \%$ fear censure or retaliation were they to do so; $24 \%$ of those surveyed have been asked by ministerial staff to alter or suppress information for non-scientific reasons; $71 \%$ believe that Canadian policy is being compromised for political purposes. Such similarities across professions are not lost on CAUT, whose 'Get Science Right' campaign is similar to its "Save LAC" campaign (CAUT, 2013).

Unfortunately, the story of librarians and archivists in recent years has many parallels. Late capitalism has put government workers in especially precarious positions as free-market ideology and the rhetoric of small government and efficiency are mobilized in attacks on professional public workers and the public sphere. The LAC story is important in that it highlights the limited impact organizations such as CAUT and CLA groups can have in resisting these attacks. The case of LAC has broad implications. Given its role as the premier cultural memory organization in Canada and the size of its staff (roughly $1,000)$, the transformation of LAC has strong reverberations throughout the entirety of two professional communities. With LAC unable to serve as the vanguard of the library and archival professions, it will take time for new national leaders to emerge.

Signs of improvement are not apparent. At the time of this writing, LAC's interim head, Hervé Déry, like his predecessor, is an economist by training, not a librarian or archivist (Akin, 2013). Furthermore, since 2012 more than a dozen federal departmental libraries have been closed including libraries at Citizen and Immigration Canada, The Canadian Revenue Agency, Parks Canada, Department of Fisheries and Oceans, Environment Canada, and Health Canada among others. The government's rationale is that electronic repositories have rendered the libraries unnecessary. While LAC has received some of the material from these libraries, LAC does not have the capacity to collect, preserve, and provide access to it. Thus, much of this material has been destroyed or sent to landfills. The current government has ignored any and all criticisms. New leadership may be able to reverse the professional weakening at LAC, but probably not without a new government. The Canadian people will have a chance to decide that in 2015.

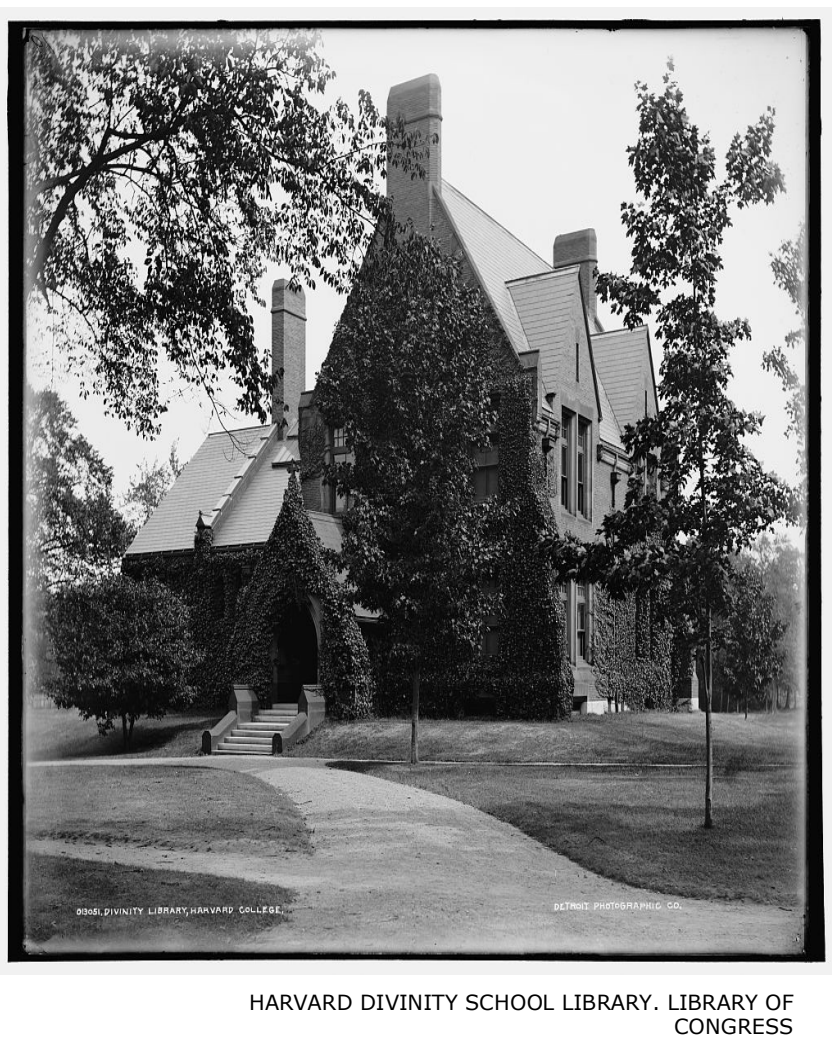




\section{References}

Adams, K. (2011, November 4). [Letter]. (Letter from Karen Adams, President, Canadian Library Association, to Wayne Peters, President, Canadian Association of University Teachers). Canadian Library Association.http://www.cla.ca/AM/TextTemplate.cfm?Section=Home\& CONTENTID=12079\&TEMPLATE=/CM/ContentDisplay.cfm.

Adams, K. (2012a). How members see us... Feliciter, 58(5), 4.http://www.cla.ca/feliciter/2012/58-5/Feliciter5_Vol_58_web.pdf.

Adams, K. (2012b, May 7). [Letter]. (Letter from Karen Adams, President, Canadian Library Association, to James Moore, Minister of Heritage and Official Languages). Canadian Library Association. http://www.cla.ca/AM/TextTemplate.cfm?Section=Home\& TEMPLATE=/CM/ContentDisplay.cfm\&CONTENTID $=12946$.

Akin, D. (2013, May 26). Who should be Canada's national librarian? A librarian or an economist. http://blogs.canoe.ca/davidakin/politics/who-should-be-canadasnational-librarian-a-librarian-or-an-economist/.

Canada. (2012). Preamble. Library and Archives Canada act. Ministry of Justice. http://laws-lois.justice.gc.ca/PDF/L-7.7.pdf.

Canadian Association of University Teachers. (2011a, June 27). Open letter to Daniel Caron, Librarian and Archivist of Canada. Canadian Association of University Teachers. http://www.savelibraryarchives.ca/files/CAUT-to-CaronLACv3.pdf.

Canadian Association of University Teachers. (2011b) Save Library and Archives Canada. Canadian Association of University Teachers. http://www.savelibraryarchives.ca/about-lac.aspx.

Canadian Association of University Teachers. (2011c). Save Library and Archives Canada-Backgrounder. Canadian Association of University

http://www.savelibraryarchives.ca/downloads/LAC-

Backgrounder-EN.pdf.

Canadian Association of University Teachers. (2012, May). Save library and archives Canada: May 2012 campaign update. Canadian Association of University Teachers. http://www.savelibraryarchives.ca/update-2012-05.aspx.

Canadian Association of University Teachers. (2013). Get science right. Canadian Association of University Teachers: http://getscienceright.ca/project/muzzling-public-science2/\#.UnPxeFCkpno.

Canadian Association of University Teachers. (n.d.). Librarians' and Archivists' Committee: http://www.caut.ca/about-us/committeesand-working-groups/librarians-and-archivists-committee.

Canadian Library Association. (1985). Statement on intellectual freedom. Canadian LibraryAssociation. http://www.cla.ca/Content/NavigationMenu/Resources/PositionSt atements/Statement_on_Intell.htm.

Canadian Library Association. (2012a, June 8). CLA continues dialogue with LAC. Canadian Library Association. http://www.cla.ca/AM/Template.cfm?Section $=$ Home\&

TEMPLATE $=/ C M /$ ContentDisplay. $. \mathrm{cfm} \& C O N T E N T I D=13020$.

Canadian Library Association. (2012b, May 2). CLA dismayed by impact of budget cuts on federal libraries. Canadian Library Association. http://www.cla.ca/AM/TextTemplate

.cfm?Section $=$ Home\&CONTENTID $=12920 \&$ TEMPLATE $=/$ CM/Content Display.cfm.

Canadian Library Association. (2012c, November). CLA member advocacy survey: The impact of federal budget cuts on Canada's libraries. Canadian Library Association. http://www.cla.ca/Content/NavigationMenu/CLAatWork/Advocacy /CLA_Member_Survey-Final_Summary_Report-Nov2012.pdf.
Canadian Library Association. (2013a, February 4). Mission, values, and operating principles. Canadian Library Association. http://www.cla.ca/AM/Template.cfm?Section=Mission

_Values_andamp_Operating_Principles\&Template=/CM/HTMLDispla y.cfm\&ContentID $=13985$.

Canadian Library Association. (2013b, March 22). LAC Code of Conduct.

http://www.cla.ca/AM/Template.cfm?Section=Home\&TEMPLATE = /CM/ContentDisplay.cfm\&CONTENTID $=14031$.

Canadian Library Association. (2013c, April 9). Letter to James Moore, Minister of Canadian Heritage and Official Languages. http://www.cla.ca/Content/NavigationMenu/CLAatWork/Advocacy /letter_to_moore_on_LAC_code_9apr13.pdf.

Caron, D. (2010). Memory institutions in the 21st century: The need for convergence and collaboration. (Speech delivered at the Archives Society of Alberta 2010 Conference, Banff, Alberta, May 13, 2010). Library and Archives Canada. http://www.baclac.gc.ca/eng/news/speeches/Pages/Memory-Institutions-in-the21st-Century-The-Need-for-Convergence-and-Collaboration.aspx.

Caron, D. (2012). Evidence before the House of Commons Standing Committee on Official Languages. 41st Parl. 1st Sess. Nov. 6, 2012. Parliament of Canada: http://www.parl.gc.ca/HousePublications/Publication.aspx?DocId $=5827447 \&$ Language $=\mathrm{E} \&$ Mode $=1 \&$ Parl $=41 \&$ Ses $=1$.

Joint statement on the qualities of a successful librarian and archivist of Canada. (2013, May 24). Canadian Association of Law Libraries.

http://www.callacbd.ca/sites/default/files/finaljoint_statement_24 may_en.pdf.

Library and Archives Canada. (2004). Creating a New Kind of Knowledge Institution: Directions for Library and Archives Canada. http://www.collectionscanada.gc.ca/obj/012012/f2/01e.pdf.

Library and Archives Canada. (2009). Biography of Daniel J. Caron. Library and Archives

Canada. http://www.collectionscanada.gc.ca/013/013-395-e.html.

Library and Archives Canada. (2010). Library and Archives internal audit: Report on the review of acquisition processes for collections. Library and Archives Canada: http://www.collectionscanada.gc.ca/obj/02014/f2/012014-308e.pdf.

Library and Archives Canada. (2013a). Census of Canada 1921 now available to researchers: http://www.baclac.gc.ca/eng/news/Pages/2013/08-1921-census.aspx.

Library and Archives Canada. (2013b). Code of conduct. Library and Archives Canada. http://www.scribd.com/doc/130187655/LAC-Code-of-ConductValues-and-Ethics\#.

Library and Archives Canada. (2013c). "End of Interlibrary loan service" service.aspx. http://www.bac-lac.gc.ca/eng/Pages/end-ill-

Library and Archives Canada. (n.d.). Response of Library and Archives Canada to Round IX Management Accountability Framework: Action Plan 2012-2013. http://www.collectionscanada.gc.ca/obj/012/f2/012-1000-e.pdf.

Lockhart, A. The Canadian Library Association's failure to advocate for librarians and libraries. Retrieved January 25, 2014, from http://plglondon.wordpress.com/2012/01/27/the-canadianlibrary-associations-failure-to-advocate-for-librarians-andlibraries/.

Martinello, F. (2013, May). Canada's universities and the loss of UCASS data: Scrambling for an alternative. Academic Matters: The Journal of Higher Education. http://www.academicmatters.ca/2013/05/canadas-universitiesand-the-loss-of-ucass-data-scrambling-for-an-alternative/. 
Martinez, P. (2013, May 17). [Letter]. (Letter from Pilar Martinez, President, Canadian Library Association, to Wayne Wouters, Clerk of the Privy Council and Secretary to the Cabinet). http://www.cla.ca/Content/NavigationMenu/CLAatWork/Advocacy /letter\%20re\%20LAC_appointment_joint_statement_may13_draf t.pdf.

Moore, K. (2012a). The concept of influence. Feliciter, 58(3), 93.

Treasury Board Secretariat of Canada. (2011). Values and Ethics Code for the Public Sector. http://www.tbs-sct.gc.ca/pol/doceng. aspx? section $=$ text\&id $=25049$. 